\title{
Pension provision recognition and assessment as a type of social capital in the context of the financial reporting socio-economic paradigm: international practice and national experience ${ }^{* *}$
}

\author{
Irina Golochalova ${ }^{1}$ \\ Doctor of Economic Sciences, \\ Moldova State University \\ JEL Classification: M41, H75
}

\begin{abstract}
In the context of the globalization of the economy, the activity of a business unit is considered as a system that includes economic, social and environmental components. As it is known, the result of the economic activity of a business unit is reflected in the financial statements, while the results of the effectiveness of the social subsystem are absent in it. In this context, the article explores the interpretation of social capital as a derivative of human capital and its socio-economic characteristics; in the context of the transition to the socio-economic paradigm of financial reporting, the identification of certain types of social capital of a business unit, and first of all, pension provision, is investigated; it also analyzes the mechanism for assessing the fulfillment of the retirement plan as a type of social capital in the framework of IFRS; the system of accounting and financial reporting of the Republic of Moldova is characterized in the context of the transition to a socio-economic concept of disclosing information on the value of a business unit; a model of accounting for the fulfillment of a retirement plan based on payments that meets the socio-economic paradigm of financial reporting is demonstrated.
\end{abstract}

Keywords: social capital; pension provision; financial reporting paradigm; fair value concept; IFRS methodology.

\section{Introduction}

It is known that within the framework of the European community, in order to ensure sustainable economic development, a development strategy has been adopted, the basis of which is a socio-economic concept. In this regard, the activity of the business unit has become regarded as a system that includes three components (economic, social and environmental subsystems). The result of the economic activity of a business unit is reflected in the financial statements, while the results of

Corresponding author:

${ }^{1}$ E-mail address: monomah5@yandex.ru

ORCID ID: 0000-0002-7552-6555

(C) 2020 I.Golochalova

doi: https://doi.org/10.26642/ppa-2020-1-18-29 
the effectiveness of the other two subsystems are absent, despite the fact that the fact of a significant impact on the cost of a business unit of a social subsystem is no longer in doubt.

According to the modern accounting methodology, the purpose of financial reporting is to provide useful information to a wide range of users, especially owners who are interested in information about changes in the cost of a business unit for making economically feasible decisions [18]. In addition, investors and other users of financial statements always need to receive reliable financial information for legal protection of their interests [1]. To achieve these goals in the financial statements, information should be provided not only about economic resources, but also about all factors (forms of capital) that create business unit value. It is obvious that the social subsystem of a business unit is formed by social capital, which is understood as economic capital transformed in a specific institutional environment under the influence of labor relations. One of the manifestations of such a transformation is the guarantee of pension provision by a business unit to its social entities.

In the context of the transition to the socio-economic concept of information disclosure, the following questions arise: Is there a conceptual justification for identifying pension provision and its recognition as a type of social capital in the financial statements of a business unit? On the basis of which method is it advisable to evaluate pension provision as a type of social capital of a business unit? Is there a single conceptual space for presenting information on social capital as a result of the participation of the business environment in ensuring sustainable development of the society in the accounting and financial reporting system of the Republic of Moldova?

The answers to these questions lie in the plane of both the institutional platform for the development of the economy social segment and the methodology of accounting and financial reporting. The main goal of the institutional platform for the development of the social subsystem of the economy is to create conditions for ensuring a fair distribution of economic benefits between all social actors, and the effectiveness of its application is manifested in assessing the contribution of social capital to the growth in value of each business unit.

Traditionally, financial statements provide information on financial capital, the result of which is reflected in the relevant balance sheet items of the Assets section, while information on other forms of capital is not reflected in it. The neutralization of this issue is possible on the basis of the financial reporting socio-economic paradigm, the occurrence of which is due to a gradual change in approaches to assessing the value of a business unit.

It is recognized that the modern accounting methodology is the IFRS methodology, evolving in the context of the transition to the financial reporting socio-economic paradigm and adapting the theory of capital, the financial management and accounting concept.

\section{Literature review}

The works of such well-known representatives of the scientific community as: P.Bourdieu [3], R.Kaplan and D.Norton [7], J.Coleman [8], T.Piketty [11] are devoted to the issue of social capital recognition as a production factor. A lot of works are connected with the study of a social capital qualitative assessment, including: A.Balcerzak [17], A.Nepp \& V.Larionova [24], R.Zamecnik [28], and others. The works of such scholars as N.Mislavskaya, A.Kharina [16], V.Tsurcanu [27] are aimed at studying the issue of assessing social through the prism of adapting the IFRS provisions. In the framework of the integrated reporting concept effectiveness attention is paid to the issues of quantitative assessment of social capital and reporting modeling in the works of A.Ageev [1], D.Pankov and A.Krupoderova [10].

Some discussion questions are considered in the works of other researchers. It should be noted that various issues regarding the quantitative assessment of social capital are discussed in the economic scientific literature, theoretical views are presented, methods and approaches are suggested, while the issue of its identification, recognition and cost estimation in the context of the transition to the socio-economic financial reporting paradigm remains open, which confirms the relevance of the topic.

\section{The identification of previously unresolved issues and the formulation of research hypotheses}

The author put forward the following hypotheses $(\mathrm{H})$ :

H1: Pension provision in the context of the socio-economic paradigm of financial reporting should be interpreted as the social capital of the business unit;

$\mathrm{H} 2$ : It is expedient to evaluate the fulfillment of the pension plan as a type of social capital in the context of the basic concept of IFRS - the concept of fair value;

H3: In the system of accounting and financial reporting of the Republic of Moldova, there is no single conceptual space for presenting information on social capital as a result of the demonstration of the business environment participation in ensuring sustainable development of society.

\section{Research methodology and methods}

Institutional platform for the development of the social segment of the economy of the Republic of Moldova: current status and prospects. It is already an undeniable fact that the socio-economic vector of public administration allows us to identify the economic model as knowledge-based, and the basic indicators formed in the social segment make it possible to characterize the level of economic development of a particular region. The Republic of Moldova is no exception. The catalyst for the development of the social segment of the economy was the European economic development strategy - «Europe 2020: A strategy for smart, sustainable and inclusive growth» (hereinafter, the "Europe 2020» strategy) in the context of recognizing the need of transition towards knowledge-based economy model. 
«Europe 2020» strategy outlined the European socio-economic concept of the 21st century and established three main factors for strengthening the economy (smart growth, sustainable growth, inclusive growth), within the framework of which a number of priority areas of a social nature have been identified (Table 1).

Since the Republic of Moldova (RM) in 2014 became an associate member of the EU, the Government of the Republic of Moldova undertook a number of obligations, including the reform of social sector legislation, which is based on the concept of assessing the social capital quality.

Table 1

The basics of the social vector of «Europe 2020» Strategy concept

\begin{tabular}{ll}
\hline Directions & Essence \\
\hline $\begin{array}{l}\text { Plan to develop new } \\
\text { abilities and increase the } \\
\text { number of jobs }\end{array}$ & $\begin{array}{l}\text { Labor markets modernization, providing citizens with the opportunity to obtain new } \\
\text { knowledge and skills, and their employment, improving the supply-demand ratio in labor } \\
\text { Directions }\end{array}$ \\
$\begin{array}{l}\text { Industrial policy for the } \\
\text { Essence }\end{array}$ \\
$\begin{array}{l}\text { globalisation } \\
\begin{array}{l}\text { European policy against } \\
\text { poverty }\end{array}\end{array}$ & $\begin{array}{l}\text { Arrangement of conditions for social and territorial interaction dissemination and employment } \\
\text { and poverty alleviation to achieve economic development throughout the EU }\end{array}$ \\
\hline Source: developed by the author based on
\end{tabular}

Source: developed by the author based on [20]

In order to implement these obligations in 2012 the Government adopted the National Development Strategy «Moldova 2020» for 2012 - 2020 (hereinafter referred to as the «Moldova 2020» Strategy). The vision of the Strategy «Moldova 2020» is to provide a socio-economic impact on priority areas, the implementation of which helps to remove barriers that impede the optimal use of resources and, first of all, human resources. Following the need for European integration, in 2019 a draft law was suggested to approve the National Development Strategy «Moldova 2030» for the next decade (hereinafter, the «Moldova 2030» Strategy), which adopts the concept of the people's quality of life in ten dimensions, according to which improving the quality of life is the strategic objective of the document.

Let's single out the main characteristic elements of each of the strategies indicated above and reveal their essence (Table 2).

We are going to dwell in more detail on the most significant provisions outlined above for the development strategies of the Republic of Moldova (Table 2). In the context of the transition, indicated by the Strategy «Moldova 2020», to a model of a knowledge-based economy and its orientation towards the development of society, one of the priority areas is the reform of the pension system, which is based on the principle of justice. The draft of Strategy «Moldova 2030» establishes the priority of the social segment of the economy, therefore, one of its components - pension provision, the system of which is subject to modernization. This fact is one of the arguments in favor of the significance of the study, in which the emphasis is on the identification of social capital, its assessment and recognition in the financial statements.

In the strategies for each of the priority areas, the current situation is analyzed, the most vulnerable groups of society are identified, a strategic vision is formulated and specific actions are provided. Thus, the Strategy «Moldova 2020» established the transition to a two-component pension system, which includes both the distribution (1st level) and cumulative (2nd level) parts. It is assumed that the pension system, which operates on the basis of the wage replacement rate, will provide citizens with a decent standard of living when they reach retirement age. In this regard, it is appropriate to emphasize that in the Republic of Moldova from 2009 to the present, the amount of social insurance contributions is $23 \%$, and the individual contributions used to determine the annual insured income are $6 \%$.

Table 2

General characteristics of the National Development Strategy of the Republic of Moldova

\begin{tabular}{lll}
\multirow{2}{*}{ Feature elements } & \multicolumn{1}{c}{ National Development Strategy: } \\
\cline { 2 - 3 } & $\begin{array}{l}\text { The transition from inertial, on the basis of } \\
\text { consumption of the model in favor of a Homocentric vision of a model of economic growth }-\end{array}$ \\
Innovative idea & $\begin{array}{l}\text { dynamic model, on the basis of attracting } \\
\text { investment and the development of } \\
\text { industries and society based on knowledge }\end{array}$
\end{tabular}

Ensuring sustainable economic development

Goal by ensuring an equitable distribution of the benefits of economic development among all

Ensuring the quality of life of people by creating the sectors of society

$\begin{array}{ll}\begin{array}{l}\text { National } \\ \text { development factors }\end{array} & \begin{array}{l}\text { Capital accumulation, labor and level of } \\ \text { productivity }\end{array}\end{array}$ necessary conditions to maintain human potential

Assessment of a person, his rights and opportunities 
End of the table 2

\section{The paradigm of economic growth}

The development of a knowledge-based society, the results of which are aimed at improving effectiveness and competitiveness

1. Education;

\begin{tabular}{lll}
\hline & 1. Education; & 1. Sustainable and inclusive economy; \\
Key areas, & 2. Access to finance; & 2. Reliable human and social capital; \\
including: & 3. Business environment; & 3. Respectable and effective institutions; \\
& 4. Pension system & 4. Healthy environment \\
\hline
\end{tabular}

Achieving the quality of life by evaluating a person who is the country's main wealth

Feature elements

National Development Strategy:

«Moldova 2020»

Only 7, including:

- development of human capital

through bringing the education system in all;

Priority directions line with labor market requirements;

- ensuring the financial stability of the pension system

A fair and sustainable pension system that provides a decent standard of living after retirement for all categories of citizens, women and men, is necessary to achieve social cohesion

In terms of reforming the pension system: - modernization of the existing distribution pension system based on the principle of solidarity (1st level);

Priority actions

- consideration of the possibility of introducing a funded pension system (2nd level)

\section{including:}

Only 10, including:

all;

-

ensuring the fundamental right to health; reliable and inclusive social protection Development of a reliable and inclusive social protection system for a sustainable and socially responsible system that adequately supports the population in overcoming the risk situation and is adapted to various crises and risks at both the micro and macro levels

In terms of modernization of social welfare provision system:

- reforming the pension system by developing a functional and sustainable three-tier system;

- ensuring the regulatory and fiscal framework for the functioning of all levels of the pension system;

- monitoring the effectiveness of the social welfare provision system in order to stimulate contributions

- stimulation of the investment process;

- increasing the financial stability of the pension system;

- contributing to poverty reduction;

Expected effect in:

overall positive consequences for

the national economy, due to the reduction of the phenomena of the shadow economy
- compliance with the principles of an effective state social insurance system and the requirements of international standards

Source: developed by the author on the basis of [21], [13]

A number of issues that pension system reform faced include:

- unequal distribution of financial resources (in violation of the basic principles of the pension system - equality and participation);

- lack of obligatory and additional private pension funds (the legislative base of non-state pension funds is not developed as the third component of pension provision, lack of motivation for employers and individuals participating in these funds) [21].

As it is known, the effectiveness of reforms is not so much in the directivity of its directions as in the effectiveness of their adaptation in practice and the results obtained, therefore, the following table will present the indicators characterizing the results of the pension reform in the Republic of Moldova (Table 3).

The Strategy «Moldova 2020» emphasized that the low replacement rate (in $2011-28.1 \%$, while the European Social Security Code recommended $40 \%$ ) was caused by the non-actualization of past income (its funded part) in determining the initial pension, which is an unprecedented fact and does not meet both international practice and the requirement of the principle of a joint system [21]. However, according to the results of the first stage of the reform of the pension system (2012-2019), the replacement rate remains low (varies within $25 \%$ ) and does not meet European standards. 
Table 3

Indicators characterizing the effectiveness of pension reform in the Republic of Moldova

\begin{tabular}{|c|c|c|c|c|c|c|}
\hline \multirow{2}{*}{ Period } & \multicolumn{3}{|c|}{$\begin{array}{l}\text { Pension expenses in the total share of the social } \\
\text { envelope }\end{array}$} & \multirow{2}{*}{$\begin{array}{c}\text { Replacement } \\
\text { rate, } \%\end{array}$} & \multicolumn{2}{|c|}{ Social Security Expenditures in GDP } \\
\hline & in $\%$ & $\begin{array}{l}\text { Pension expenses, } \\
\text { euro }^{2}\end{array}$ & $\begin{array}{l}\text { Social envelope, } \\
\text { euro }\end{array}$ & & in $\%$ & GDP, euro \\
\hline 2011 & 67.8 & 325215.20 & 474340.54 & 28.2 & 8.8 & 5452820.17 \\
\hline 2016 & 59.1 & 423595.56 & 719514.20 & 26.1 & 8.5 & 8352130.20 \\
\hline 2017 & 55.3 & 474113.60 & 858097.18 & 24.9 & 9.9 & 8592307.69 \\
\hline 2018 & 56.8 & 571072.68 & 1005582.21 & 23.8 & 10.7 & 9344262.30 \\
\hline 2019 & 63.6 & 701536.51 & 1104504.20 & 25.9 & 11.5 & 9545618.50 \\
\hline
\end{tabular}

Source: developed by the author on the basis of [25]

The well-known scientist T.Piketty (2016), considering the transition from the distribution form of the pension system to the funded one, notes that there is an opinion that, in conditions when the return on capital is higher than economic growth and there is economic benefit from capitalized pension contributions, the funded system is more preferable and distribution pension systems need to be replaced as soon as possible [11]. However, from his point of view, the distribution system provides a reliable level of pensions and will remain an effective part of the pension system of the future, and its funded part should be adapted by each business unit (business environment) depending on individual situations that are diverse and related to the characteristics of a professional activities [11]. In this context, it follows that the effectiveness of the funded system appears when the employer creates a special pension fund separate from the employer.

The following table presents the current state of pension provision within the social segment of the Republic of Moldova, using for this purpose information from the National Bureau of Statistics (NBS), as well as other official publications (Table 4).

According to the table, the increase in pension payments on average is $12 \%$, part of which is due to the annual level, varying from $7.5 \%$ to $6.3 \%$ in the periods under review. Based on the data presented in Tables 3 and 4, today the RM pension system is difficult to characterize as financially effective in the long term, although it has adapted modern methods of calculating benefits.

Table 4

Information on pension recipients and their payments in the Republic of Moldova

\begin{tabular}{|c|c|c|c|c|c|c|c|c|c|}
\hline \multirow[b]{2}{*}{$\begin{array}{l}\text { Types of } \\
\text { Pensions }\end{array}$} & \multicolumn{3}{|c|}{ As of October 1, 2017} & \multicolumn{3}{|c|}{ As of October 1, 2018} & \multicolumn{3}{|c|}{ As of October 1, 2019} \\
\hline & 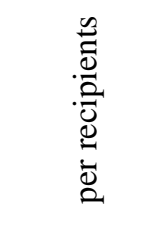 & 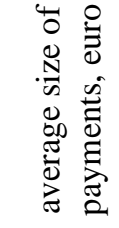 & 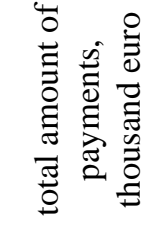 & 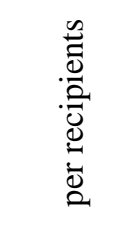 & 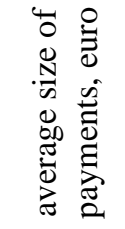 & 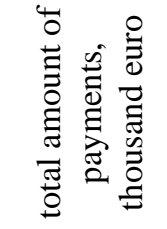 & 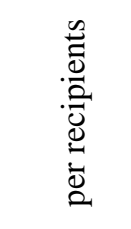 & 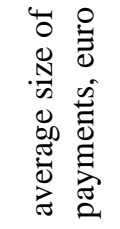 & 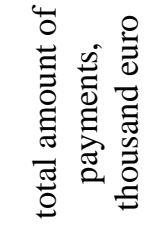 \\
\hline $\begin{array}{l}\text { Pensions total, } \\
\text { including: }\end{array}$ & 7182852 & 73.28 & 52635.92 & 708761 & 85.57 & 60654.28 & 700887 & 97.93 & 68642.37 \\
\hline by age & 536513 & 69.82 & 37462.76 & 530895 & 81.49 & 43265.77 & 527710 & 94.79 & 50022.27 \\
\hline $\begin{array}{l}\text { by limited } \\
\text { opportunities }\end{array}$ & 129654 & 55.02 & 7133.92 & 125524 & 63.77 & 8004.47 & 123448 & 73.97 & 9132.32 \\
\hline $\begin{array}{l}\text { by length of } \\
\text { service }\end{array}$ & 67 & 38.68 & 2.59 & 62 & 42.86 & 2.657 & 59 & 50.15 & 2.959 \\
\hline $\begin{array}{l}\text { certain } \\
\text { categories of } \\
\text { civil aviation } \\
\text { workers }\end{array}$ & 611 & 362.36 & 221.403 & 571 & 420.50 & 240.057 & 549 & 447.6 & 243.733 \\
\hline $\begin{array}{l}\text { participants of } \\
\text { liquidation of } \\
\text { consequences } \\
\text { of the } \\
\text { Chernobyl } \\
\text { accident }\end{array}$ & 1817 & 148.85 & 270.461 & 1758 & 167.54 & 294.537 & 1721 & 195.1 & 335.722 \\
\hline $\begin{array}{l}\text { early } \\
\text { retirement } \\
\text { pension }\end{array}$ & 6020 & 133.55 & 803.98 & 7721 & 152.23 & 1175.38 & 6257 & 161.8 & 1013.36 \\
\hline $\begin{array}{l}\text { other } \\
\text { categories }\end{array}$ & 43603 & 154.13 & 6670.80 & 42230 & 181.70 & 7671.41 & 41143 & 191.8/ & 7892.0 \\
\hline
\end{tabular}

Source: developed by the author on the basis of [25]

\footnotetext{
${ }^{2}$ When recounting information data, the author used the official exchange rate as of December 31 of the corresponding reporting period, presented on the official website.
} 
This conclusion is generally consistent with the opinion of T.Piketty (2016) as when reforms do not take into account the diversity of professional activities, pension systems become extremely complex, have dozens of regimes, use different rules, which inevitably leads to underestimation of the resources allocated to finance pension systems [11].

The draft of «Moldova 2030» Strategy declares that the state social security system is an integral part of the social protection system, the main purpose of which is to guarantee the insured person's income by providing cash benefits to insured persons who cannot receive income in the form of wages in case of certain risks.

The social security system is subject to modernization (Table 2), in part of which priority actions are aimed at:

- strengthening the 1st level as the main prerequisite for the development of the 2nd and 3rd levels of pension provision on the basis of observing the principle of justice;

- the formation of the mandatory public (distribution) component of pension provision based on the principles of contributions;

- determination of the mandatory cumulative (funded) component of the pension formed in the state or private insurance system (2nd level), which ensures the perfect ratio of pension to the amount of social insurance contributions;

- the establishment of an optional (distributive) component of the pension formed in the private social insurance system (3rd level), which enables everyone to make an additional contribution to ensure an increase in the size of pensions.

The developers of the «Moldova 2030» Strategy believe that the application of the indicated model of pension provision will contribute to the revitalization of the investment process by accumulating social insurance contributions that will be accumulated in pension funds and not immediately used to pay off pension obligations.

Since the core of the institutional platform is legislation, it is expedient to identify the legislative acts of the Republic of Moldova governing the functioning of the pension system as part of the social insurance system and to reveal their most significant provisions. In this context, in order to classify the social security approach adopted in the Republic of Moldova as one of the two indicated models, this is a necessary condition for putting forward the author's research hypothesis.

Analysis of the legislative framework of the pension system of the Republic of Moldova: realities and prospects. The national legal framework of the current pension system in the republic is represented by special legislative acts, to which, in order to fulfill the obligations under the EU-RM Association Agreement, a number of changes and additions are made: Law No. 156 of October 14, 1998 «On the State Pension System» (with the latest amendments that entered into force on January 01, 2019) (hereinafter, Law No. 156); Law No. 489 of July 08, 1999 «On the State Social Insurance System» (with the latest amendments that entered into force on January 01, 2019) (hereinafter, Law No. 489). The Law on the State Social Insurance Budget is developed annually.

To implement the concept of developing a non-banking financial market for 2018-2022, the National Commission for Financial Markets developed a draft Law on Optional Pension Insurance Funds - «On Optional Pension Funds», which is submitted for approval to the Parliament of the Republic of Moldova and is the result of the transposition of Directive 2011/61 of June 08, 2011 and amendments to Directives 2003/41 and 2009/65, Regulation (EC) No 1060/2009 and Regulation (EU) No 1095/2010, as well as EU Regulations governing various types of collective investment organizations [12].

Here is a general description of the legislative acts regulating the legal basis for the effectiveness of the pension system of the Republic of Moldova (Table 5).

As it is known, the execution of legally fixed contracts, which include the insurance contract, is reflected in the financial statements. The accounting procedure and the preparation of financial statements are regulated by the new law - Law No. 287 of December 15, 2017 «On Accounting and Financial Reporting» (hereinafter, Law No. 287), which entered into force on January 01, 2019 and was developed in accordance with action plan for the implementation of the EU-RM Association Agreement.

Articles 6 and 20 of the mentioned law in order to recognize financial statements as clear, giving an accurate idea of the financial situation, the reporting organization is required to comply with: fundamental assumptions, accounting principles and requirements for the quality of the presentation of information (qualitative characteristics) [22]. Also, Law No. 287 regulates the organization of accounting, the composition of individual and consolidated statements, the contents of the explanatory note and management report, the procedure for submission and publication [22].

Table 5

General characteristics of the basic provisions of legislative acts regarding pension provision

\begin{tabular}{|c|c|c|c|}
\hline Law & Aim & Article & Summary \\
\hline $\begin{array}{l}\frac{0}{0} \\
\frac{0}{0} \\
\bar{D}\end{array}$ & 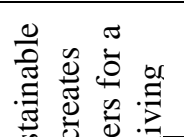 & 1 & $\begin{array}{l}\text { It establishes the legal framework for the functioning of the state pension system, as well } \\
\text { as its interaction with the state social insurance system as a whole and other mechanisms } \\
\text { of social protection of the population }\end{array}$ \\
\hline 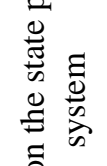 & 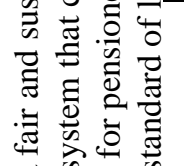 & $8\left(1^{1}\right)$ & $\begin{array}{l}\text { It gives concepts, including: valorization - indexation of the average monthly insured } \\
\text { income received from January } 1,1999, \text { which is carried out taking into account the } \\
\text { coefficient of growth of the average wage in the economy during insurance periods up to } \\
\text { the year preceding the appointment }\end{array}$ \\
\hline $\begin{array}{l}\dot{0} \\
\stackrel{0}{n} \\
\dot{n} \\
\dot{2}\end{array}$ & 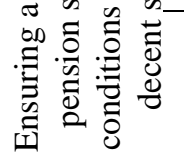 & $\begin{array}{c}6,8,13 \\
42,49\end{array}$ & $\begin{array}{l}\text { It determines the calculation mechanism: length of service, average monthly insured } \\
\text { income, indexation coefficient, expenses on paying pensions, valorized average monthly } \\
\text { insured income, old-age pension }\end{array}$ \\
\hline
\end{tabular}


End of the table 5

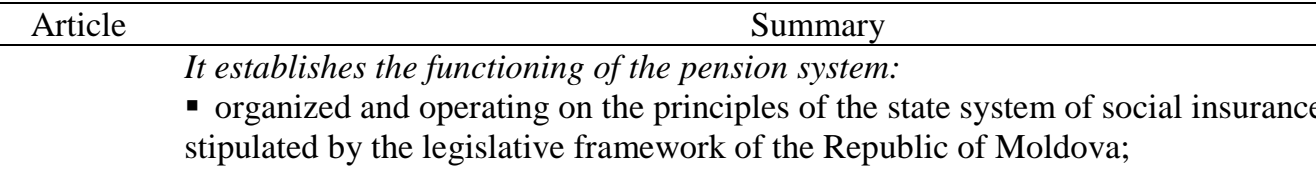

$1^{1}, 4,5$, - whose source of effectiveness is funds of the pension fund, formed from contributions

8,9 , from the state social insurance, transfers from the state budget and other funds;

14-27, - stipulating the identification of pensions by their types and rights to them;

30-40 - which is based on determining the size of the pension based on the average monthly insured income;

- stipulating the indexation of pensions in the part of the state social insurance budget funds;

- including guaranteeing and implementing the procedure for assigning and paying pensions Establishes the legal framework for the implementation of the right to social insurance.

\begin{tabular}{ll}
2 & Establishes the legal framework for the implementation of the right to social insurance. \\
\cline { 2 - 2 } & Provides a definition of concepts, including: \\
- social insurance - a social security system that ensures the provision of pensions and a \\
number of benefits to the insured by the legislation;
\end{tabular}

- insured person - an able-bodied individual, subject to compulsory state social insurance in order to obtain rights that prevent, limit or eliminate social risks;

- state social insurance budget - a set of incomes, expenses and sources of financing intended for the implementation of the functions of the state insurance system and its

1 management;

- reserve fund of the state social insurance budget - a fund of cash funds intended to pay social insurance benefits in justified cases and to cover other expenses of the state social insurance system provided for by the annual law on the social insurance budget;

- insurance contract - a mutually binding bilateral agreement between a legal entity or an individual using paid work, on the one hand, and a territorial body of the National Fund, on the other hand, defining the rights and obligations of the parties in the field of social insurance

36 Determines the calculation mechanism: the length of service of social insurance

Establishes the procedure of the social insurance system functioning:

- acting on the basis of principles, including the social solidarity of generations, commitment, participation, distribution and independence;

$3,4,5,7$, aimed at identification of: persons subject to compulsory social insurance, social insurance benefits, including pensions;

10-16, - the source of effectiveness of which is the funds of the state social insurance budget,

$17,22, \quad$ formed at the expense of contributions of payers;

36 - based on the determination of the size of social and individual contributions of social insurance, based on the monthly insured income,

- taking into account the length of service calculated in the years for which contributions were paid

It regulates legal relations in the system of optional pensions (3rd level), which does not

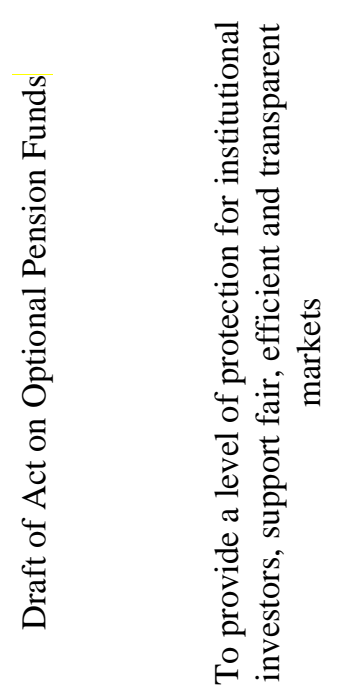
limit the participation of social entities and is created on the basis of voluntary contributions of employees and / or employers

It envisages the following functioning scheme of the optional fund:

- voluntary participation of the employee, in which the amount of contributions made is established upon conclusion of a separate act of joining the fund;

- the employer will offer his employees an optional pension plan and will pay contributions that can be divided between the employee and the employer in accordance with the provisions of the collective labor contract;

- the fund becomes an effective tool for motivating employees and managing human resources

It defines the administration model for asset management of optional pension funds that can be implemented by:

- a pension company (JSC established solely for the purpose of creating and managing an optional pension fund);

- a regulated institution from the financial sector;

- branches of legal entities authorized to conduct such activities in other states established in the Republic of Moldova under the conditions of obtaining a license in accordance with the provisions of the legislation of the Republic of Moldova 
International experience for the sustainable development of the economy has developed several models for supporting its social segment, of which Ageev et al. (2017) put forward the Anglo-Saxon and European models as the most effective. The Anglo-Saxon model is based on the responsibility of the business environment to society and is limited to creating jobs, ensuring their efficient use through wages, creating working conditions and paying taxes, and uses the institution of corporate funds to participate in social support of the company, with the European model social support of society is provided by the state through the implementation of socially significant programs and projects, and the business environment and other subjects of taxation pay relatively large taxes [1]. The difference between these two models is due to the degree of state participation in social support of society.

Based on the mentioned above, the conclusion is as follows: in the Republic of Moldova, a single-level pension system is currently operating on the basis of the state pension fund, which, although it gravitates to the European model of supporting the social segment, however, for a number of reasons it does not have the ability to adapt all the tools of this model.

This trend is fully consistent with the orientation of the RM accounting system to the continental (European) model, according to which the financial statements are prepared on the basis of a legal approach in accordance with the concept of "directivity and clarity", which is stated in Law No. 287, despite the fact that the basic principle of preparation reporting is the substance over form principle [22, Art. 6], and the purpose of financial reports is to provide useful information necessary for making economic decisions by a wide range of users [23, Art. 6]. As it is known, under the Anglo-Saxon model of an accounting system, financial statements are prepared in accordance with the economic approach, based on the concept of «truthful and fair presentation», hence here is the the substance over form principle. The author considers it appropriate to note that a feature of the national accounting and reporting system of the Republic of Moldova is not so much its directivity as inconsistency.

\section{Main results}

As it is already known, in the framework of the European community, in order to ensure sustainable economic development, a development strategy has been adopted, the basis of which is a socio-economic concept. The catalyst for this concept is human capital, the effective use of which ensures high competitiveness and a leading position in the current economic market both at the micro and macro levels. In this regard, the activity of the business unit has become regarded as a system that includes three components (economic, social and environmental subsystems). The result of the economic activity of the business unit is reflected, while the results of the effectiveness of its two other subsystems are absent in the financial statements, despite the fact that the fact that the social subsystem affects the value of the business unit is no longer in doubt. To neutralize the problem of disclosing information about the factors that create the value of a business unit, it is necessary to clearly identify them as a separate form of capital and develop a model for its accounting.

At present, the issue of assessing the human factor is widely studied, and in a number of works it has already been proved that its influence on the total value of a business can be valued. As a result, from the perspective of a modern accounting methodology oriented towards the socio-economic paradigm of financial reporting, it should be reflected in the financial statements: on the one hand, in the «Assets» section, on the other hand, in the «Liabilities» section, but as what element, capital or liability? To answer this question the disclosure of the essence of capital and the identification of the object of observation as such will help. In this context, one cannot disagree with the opinion of A.Bodyako (2017) that the classical interpretation of capital has not undergone significant changes and consists in its understanding as a combination of goods and property of the owner, which brings economic benefits and ultimately allows them to receive additional income [2]. As you know, capital is characterized from two sides: by the composition of various objects of value and by sources (advanced capital and income from it). In this regard, the following question arises: in what form should the effect of the human factor be represented?

The issue of identifying new forms of capital due to the use of human resources is not new, and for each of them, there is a concept with its own history of development and formation. Human resources are a combination of various human qualities that determine its $\alpha$ - and $\beta$-activity, used by the business environment. It is believed that it is human $\beta$-activity, as an intellectual and creative activity, that contributes to the creation of competitive advantages and, as a result, capital growth, and there is a need to identify this production factor as a structural component of capital.

Under these conditions, many new concepts have emerged both in the field of the economic theory of capital as well as management aimed at solving this issue.

We emphasize that the conceptual aspects of the interpretation of the forms of capital generated by the manifestation of $\beta$ activity of a person, such as intellectual, human, organizational through the prism of the concepts of organization and resource management are described in detail in [27]. Therefore, in the framework of this study, we dwell only on the key points in identifying forms of capital.

Famous economists L.Edvinsson and M.Malone (1997) believe that human $\beta$-activity contributes to the formation of intellectual capital and outline in its structure human capital (knowledge, skills, abilities, moral values, work culture) and structural capital (technologies and software) [19].

The key role is given to new forms of capital in resource theory (English version, resource-based view - RBV), the concept of managing a business unit to achieve competitive advantages. According to this concept, resources are understood as factors of the production process as the capital of a business unit, and ability is a group of resources used to carry out a specific task or activity. In this regard, according to one of the ideologists of resource theory, R.Grant (2003), along with traditional factors of production, it is necessary to single out human, reputational, and organizational factors [4]. At the same time, human capital is 
understood as a combination of innate abilities, acquired knowledge, skills and motivations, the effective use of which helps to increase incomes and other benefits and which is characterized by a socio-economic form. Organizational capital is a technology, procedures, management system, communication culture, software, communication structure, consumer capital is a system of stable ties and relations with customers and consumers, and, therefore, both of these forms of capital are derived from human capital because they represent the ability to apply it effectively.

Today, the study of the essence of capital by T.Piketty (2016) has received worldwide recognition. From his point of view, the process of economic growth is characterized by the fact that the importance of skills, abilities, more broadly - human labor, and gradually increases in the production process [11]. It seems natural that technology was gradually transformed in such a way that the human factor in the 21 st century began to play a larger role than before: its share in the aggregate factors of production increased as a result of its increasing importance in the production process. It follows from this that an increase in the share of human capital reduces the share of production and financial capital, and, as a result, changes the structure of owners' capital under the influence of various forms, the emergence of which, according to T.Piketty, is caused by «a change in the negotiating position of labor (the human factor) and financial capital» [11].

In the context of these theories, such a form of capital as social capital has been singled out. We will reveal its essence and interpretation. The founder of the theory of social capital P. Bourdieu (1983), identifying capital depending on the area of its functioning, highlighted its three forms: economic, cultural, social. Economic capital is directly converted into money and institutionalized as a right of ownership of a particular property, cultural and social capitals are converted into economic capital only under certain conditions and institutionalized as a right to receive income (remuneration) from qualifications or specific titles [3]. According to this concept, social capital:

- is a set of real or potential resources that arise in an individual or group in connection with institutionalized relations;

- depends on both the size of the bonds and the amount of capital that each individual or group has;

- although it is used both for individual, group or collective purposes, it cannot be measured on an individual level;

- provides an opportunity for network members to receive economic benefits (material and symbolic rewards) that are formed and maintained for a long time;

- requires investment strategies to neutralize the inequality of remuneration for equivalently invested capital (economic and cultural) according to the degree of mobilization of the group [3].

Another contemporary researcher of the essence of social capital, J.Coleman (2001), expanded its interpretation according to which social capital is total resources that simultaneously contribute to the development of human capital and are a byproduct of human activity [8]. In other words, social capital facilitates production activities, despite the fact that it is practically intangible, since it appears only in relationships with a high degree of trust between social actors.

Another interpretation of social capital is normative and value one suggested by Fr.Fukuyama (2003). According to this scientist, social capital is a combination of social norms, values, social exchanges that make up the institutional environment, and, therefore, it is a public good that assumes a basic level of trust reflected in a social contract [15]. In the framework of this interpretation, social capital is produced and saved by social institutions and, above all, by the state.

As part of the disclosure of the evolution of the concepts of social capital, A.Svenitsky \& L.Pochebut (2009) conclude that social capital is a resource that can be converted into human capital, financial capital, intellectual, investing in it both own investments, and investments of partners, but with respect to which reliable and tested measurement methods have not yet been developed [14].

Exploring the issue of the essence of capital in the 21 st century, T.Piketty noted the fact that a high share of owners' capital is due to the transition of civilization to an economic model based on human capital and personal virtues, and this requires a change in the structure of capital, primarily through recognition of human and social capital [11]. In his opinion, social capital, which brings together social entities that are similar in some aspect, like other forms of capital, brings dividends, but only if it is actively used at the macro level, micro level and through exchange.

This approach is consistent with the concept of integrated reporting, embodied in the International Standard «Integrated Reporting». The basic idea of the standard is as follows: the amount of capital is not static over time, one type of capital is converted to another and a constant cycle occurs between them (some types decrease and others increase) [9, p. 2.12].

To disclose information on the creation of the value of a business unit, data on resources as well as on established business relationships called capitals, which are divided into financial, industrial, intellectual, human, social and reputational, natural [9, p. 2.3], is required. According to the specified standard, social and reputational capital includes: general norms and values, behavioral patterns, relationships / connections, trust and willingness to cooperate, social licenses for the work of a business unit, goodwill [9, clause 2.15].

Based on the analysis of existing interpretations, it seems logical to conclude that social capital is a derivative of human capital and has similar socio-economic characteristics: it is peculiar to a certain group of individuals (ties), is formed by the institutional environment, is converted into financial capital, brings dividends in the future, changes its value in time, requires investment support, affects the total value of a business unit.

In the context of the socio-economic paradigm of financial reporting, the key role is given to new forms of capital - human, social and organizational (hereinafter, the HSO), since they have a significant impact on the total value of the business. However, to determine and disclose this effect in the financial statements in the context of each form of capital, it is necessary to develop a conceptual position regarding their assessment.

Conceptually rethinking of the estimation of the HSO capitals is indicated in the work of R.Kaplan and D.Norton (2003): traditional financial statements are inadequate to the requirements of the innovative vector of the economy, since the HSO capitals are not reflected in it, although the result of their impact on business value is much more significant than physical capital [7]. R.Kaplan and D.Norton see the neutralization of this problem in the use of the concept of fair value measurements. 
In relation to the problem of assessing HSO capitals, it is appropriate to single out the work of R.Zamecnik (2016), in which the complex of methods for assessing human resources is considered. In the framework of the study, R.Zamecnik noted that in most cases the procedure for assessing human resources is based on quantitative indicators.

He sees one of the main problems in the assessment and accounting of human resources in the difficulty of measuring their qualitative parameters, which form the basis of the income approach of assessment. One cannot disagree with his other opinion that for the effectiveness of the assessment of human resources, clear recommendations for application are required, since each of the existing methods has its advantages and disadvantages, and distorted evaluation results can lead to dehumanization of the business unit [28]. Researcher A.Balcerzak (2016) adheres to a similar view, according to which a multi-criteria analysis of human resources is necessary, and their assessment should be based on qualitative parameters, without which it is impossible to create competitive advantages and create a high business value in the knowledge-based economy [17].

We should separately dwell on the work of A.Nepp \& V.Larionova (2018), in which it was established that the basic parameters of the pension savings system include investment parameters - the rate of return on investment, return on investment of pension savings [24]. The results of this study confirm the need for an income-based approach to assessing social capital.

An analysis of the specialized literature indicates a steadily growing attention to the issue of valuation of HSO capitals. However, it is appropriate to emphasize that in relation to the assessment of social capital, attention is mainly focused on its assessment at the macro level, and only occasionally at the micro level.

From the point of view of applied nature, the work of A.Kharin (2017) deserves attention, in which the author, studying approaches to assessing social capital, concludes that the development of a universal approach is difficult due to the abstractness and lack of unity of methods for its assessment. However, in his opinion, which one cannot disagree with, when identifying a specific form of social capital, uncertainty can be avoided and, based on the income approach, one can choose a method for its best assessment. An analysis of the applicability of valuation methods is based on the provisions of IFRS [16].

Hypothesis H1 is argued by the above mentioned author: Pension provision in the context of the socio-economic paradigm of financial reporting should be interpreted as the social capital of a business unit, which must be evaluated and recognized as elements of financial reporting: on the one hand, as an asset, on the other, as capital. The influence of recognition of pension provision as a type of social capital on the balance sheet content is presented in Fig. 1.

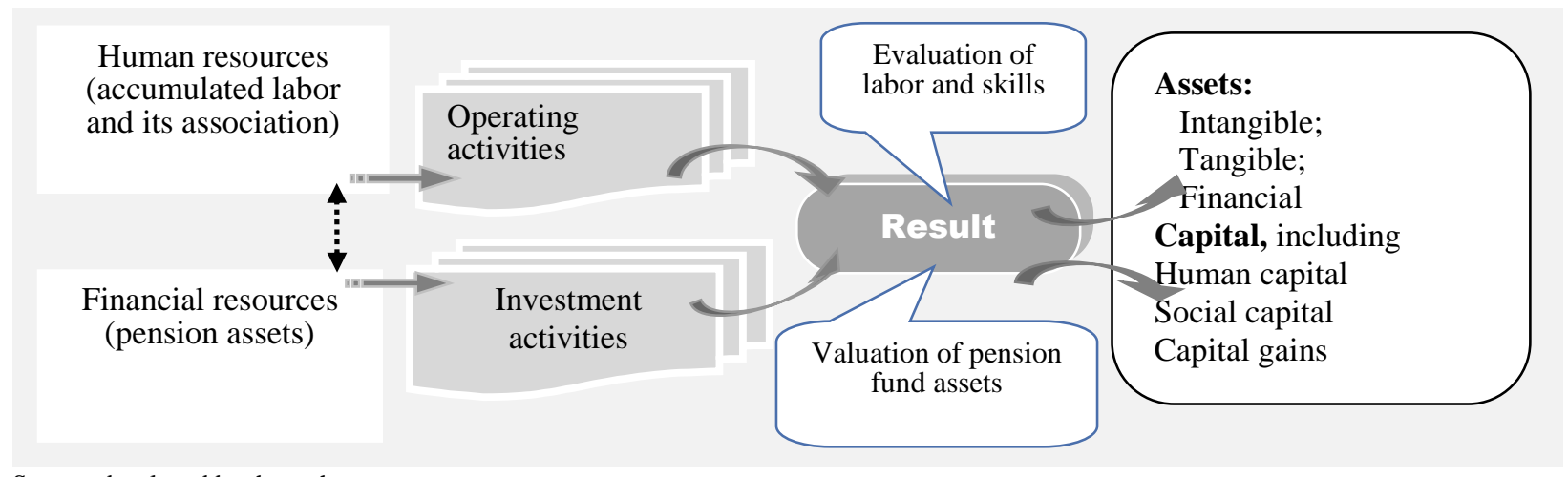

Source: developed by the author

Fig. 1. The effect of social capital recognition on the balance sheet

In this context, it is appropriate to note that this position is fully consistent with T.Piketty's opinion: each participant in a particular pension system should think over decisions in the field of savings and property accumulation, since a pension is the property of those who do not have property (capital) [11].

The listed works undoubtedly make a significant contribution to solving the issue of assessing social capital, but they did not address such issues as the valuation mechanism, accounting models, and the format of information in the context of the socio-economic paradigm of financial reporting.

In this regard, the work of D.Pankov and A.Krupoderova (2014) should be noted. The authors developed a methodology for assessing the social factor in order to establish the total value of human capital, suggested an accounting procedure and developed a balance model [10]. However, this is a methodology for the quantitative assessment of HSO capitals and is focused on the integrated reporting concept.

According to the author, the concept of measurement that meets financial reporting socio-economic paradigm is the concept of fair value measurement - the basic idea of the IFRS methodology. Within the framework of this concept, depending on the form of capital, one or another valuation method foreseen by the basic standard is used. Since the object of this study is pension provision, identified as the social capital of a business unit, we will reveal the procedure for its assessment based on the provisions of IFRS.

It is known that at the international level, the procedure for assessing and recognizing pensions in the context of the fulfillment of their plans is governed by IAS 19 «Employee Benefits», which distinguishes two types of pension plans: with defined contributions and with defined benefits. As a rule, accounting for defined contribution pension plans that assume that a business unit makes fixed contributions to a separate fund and will not have any legal or imputed obligations to pay additional contributions is not difficult. Typically, government pension plans are of this kind. 
Since the condition of defined benefit pension plans is the obligation of the company to provide remuneration of the agreed size for existing and former employees, which takes into account all the financial risks arising from the economic situation in the current market, a special assessment mechanism is required for their fulfillment. Let's briefly dwell on it.

According to IAS 19, defined benefit plans envisage setting up special organization or fund separate from the business unit where it transfers contributions and where payments are made to pay off debts to employees. The purpose of the fund is to effectively use the funds received by investing them in securities - stocks and bonds (financial instruments).

Fulfillment of the defined benefit pension plan requires, on the one hand, recognition of these investments, which are treated by IAS 19 as plan assets, and on the other, obligations to employees. Since investing is characterized by a long-term nature and an element of estimated uncertainty, the cost of investment varies over time. According to the designated standard, plan assets should be measured at fair value at the reporting date, and liabilities on a discounted basis, which should reflect an estimate of expected future salaries and the results of traditional employer practices.

It should be noted that the assessment and recognition mechanism of pension plans with defined payments in accordance with IAS 19 is described in detail in [26].

By above mentioned, the author argues hypothesis $\mathrm{H} 2$ : the assessment of the pension plan fulfillment as a type of social capital should be carried out in accordance with the provisions of IAS 19, which meet the fair value concept.

In accordance with the argumentation of hypotheses H1 and H2, the author believes that the fund, which is formed by making contributions by social entities, is inherently the social capital of a business unit, designed to confirm the right (guarantee) to a share in the business value of social entities (the owner) and bring them additional income (dividends). Based on this, the pension plan, as a result of the pension agreement fulfillment between the social entity and the business unit, should be represented by two balance sheet items: plan assets and the social capital of the pension provision.

The author's opinion is also consistent with the provisions of IAS 19, which interpret the increase (revaluation) of the net value of the pension plan assets with defined payments as other comprehensive income and require its reflection in the reporting under one of the articles in the Capital section. The suggested accounting model for the payment-based retirement plan fulfillment that meets financial reporting socio-economic paradigm is presented in Table 6.

Table 6

Accounting model for the fulfillment of the retirement plan

\begin{tabular}{cccc}
\hline \multirow{2}{*}{$/ \mathrm{n}$} & Contents of transaction & \multicolumn{2}{c}{ Corresponding accounts } \\
\cline { 3 - 4 } & Pension contributions made & Cash Funds & $\mathrm{Ct}$ \\
\hline 1 & Pension plan assets recognized & Pension Plan Assets & Cash Funds \\
\hline 2 & Pension benefits accrued & Social capital & Pension Obligations \\
\hline 3 & $\begin{array}{c}\text { Valuation of plan assets at the } \\
\text { reporting date }\end{array}$ & Plan assets & $\begin{array}{c}\text { Retained earnings for the } \\
\text { reporting period }\end{array}$ \\
\hline 5 & Pension payments made & Pension Obligations & Plan assets \\
\hline Source: developed by the author & &
\end{tabular}

As it has been already indicated, a single-level pension system based on the state pension fund is currently operating in Moldova, and the creation of a combined pension system is envisaged in the near future. It is known that the national system of accounting and financial reporting is characterized by directivity, as evidenced by the approval of the forms of financial statements. Moreover, Law No. 287 stipulates the use of a legal approach in the preparation of financial statements, and, as a result, the application of the concept of fair value measurements, in addition, as well as the transition to financial reporting socio-economic paradigm, is not yet provided for.

The above gives reason to believe that in the national system of accounting and financial reporting of the Republic of Moldova there is no single conceptual space for presenting information on social capital as a result of the demonstration of the business environment participation in ensuring sustainable development of society.

\section{Concluding remarks}

Based on the results of the study, the following conclusions are drawn in this work: social capital is a derivative of human capital and has similar socio-economic characteristics, including those: is formed by the institutional environment, is converted into financial capital, brings dividends in the future, changes its value over time; in the context of the transition to financial reporting socio-economic paradigm the retirement plan should be interpreted as the social capital of the business unit, the performance results are identified as elements of the financial statements: on the one hand, an asset, on the other, capital; it is expedient to evaluate the fulfillment of the retirement plan as a type of social capital in accordance with the provisions of IAS 19, which meet the concept of fair value; in the system of accounting and financial reporting of the Republic of Moldova in the context of the transition to the socio-economic concept of information disclosure, there is no conceptual space in terms of obtaining reliable information about the contribution of social capital to the total value of a business unit.

As part of the study, the author suggested a model of accounting for the fulfillment of a payment-based retirement plan that meets financial reporting socio-economic paradigm. 


\section{References:}

1. Ageev, A., Galushkina, M., Kopkova, E., Smirnova, V. and Shtukel'berger, K. (2017), Integrirovannaja otchetnost': vyzov menedzhmentu, Institut jekonomicheskih strategij, Nacional'nyj centr nauchno-tehnicheskoj informacii, Moskva, $212 \mathrm{p}$.

2. Bodjako, A. (2017), Problemy razvitija metodologii ucheta i kontrolja v uslovijah institucional'noj jekonomiki innovacionnogo tipa, Vol. 3, O perspektivah «cifrovogo formata» ucheta, kontrolja i otchetnosti, RUSAJNS, Moskva, $254 \mathrm{p}$.

3. Burd'e, P. (1986), «Formy kapitala», Translated by Dobrjakovoj, M., in Radaev, V. (ed.), Jekonomicheskaja sociologija, pp. 241-258, [Online], available at: https://gtmarket.ru/laboratory/expertize/2009/2601\#1.3

4. Grant, R. (2003), Resursnaja teorija konkurentnyh preimushhestv: prakticheskie vyvody dlja formulirovanija strategii, Vestnik $S P b G U$, Serija Menedzhment, No. 3, pp.47-75.

5. Respubliki Moldova, Zakon (1998), O gosudarstvennoj pensionnoj sisteme, No. 156 ot 14.10 (s poslednimi izmenenijami, vstupivshimi v silu s 01.01.19), [Online], available at: http://lex.justice.md/viewdoc.php?action=view\&view=doc\&id=313291\&land

6. Respubliki Moldova (1999), O gosudarstvennoj sisteme social'nogo strahovanija, Zakon No. 489 ot 07.08 s poslednimi izmenenijami, vstupivshimi v silu s 01.01.19, [Online], available at: http://lex.justice.md/ru/311675/

7. Kaplan, R. and Norton, D. (2003), Sbalansirovannaja sistema pokazatelej: ot strategii k dejstviju, ZAO «Olimp - Biznes», Moskva, 214 p.

8. Koulman, Dzh. (2001), «Kapital social'nyj i chelovecheskij», Translated by Strel'nikova, L. and Stasenko, A., Obshhestvennye nauki $i$ sovremennost', No. 3, pp.121-126.

9. Mezhdunarodnyj standart «Integrirovannaja Otchetnost'», [Online], available at: https://integratedreporting.org/2015.03/13-1

10. Pankov, D. and Krupoderova, A. (2014), Model' stoimostnoj ocenki «chelovecheskogo kapitala - funkcii» i metodika ego otrazhenija v sostave integrirovannoj otchetnosti bjudzhetnyh organizacij, [Online], available at: https://www.empas.pb.edu.pl/media

11. [Online], available at: DOI: 10.12846/j.em.2014.03.19

12. Piketti, T. (2016), Kapital v XXI veke, Ad Marginem Press, Moskva, 592 p.

13. Proekt Zakona o fakul'tativnyh pensionny fondah, [Online], available at: https://www.parlament.md/\%d0\%97

14. Proekt Nacional'noj strategii razvitija «Moldova - 2030», [Online], available at: https://www.parlament.md/\%d0\%97

15. Senickij, A., Pochebut, L., Kilishenko, M. and others (2009), «Social'nyj kapital i ego formirovanie: social'no-psihologicheskij podhod», Vestnik Sankt-Peterburgskogo universiteta, Ser. 12, Issue 3, Part 2, pp. 140-147.

16. Fukujama, Fr. (2003), Velikij razryv, [Online], available at: https://library.khpg.org/files/docs

17. Harin, A. (2017), «Social'nyj kapital organizacii: ponjatie i metody ocenki», Jekonomicheskij analiz: teorija i praktika, Vol. 16, Issue 4, [Online], available at: https://cyberleninka.ru/article/n/sotsialnyy-kapital-organizatsii-ponyatie-i-metody-otsenki

18. Balcerzak, A. (2016), «Multiple-criteria evaluation of quality of human capital in the European Union countries», Economics and sociology, Vol. 9, No. 2, pp. 11-26, [Online], available at: DOI:10.14254/2071-789X.2016/9-2/1

19. Conceptual Framework for Financial Reporting, [Online], available at: http://www.ctcp.gov.co/files/documents

20. Edvinsson L. and Maloune, M. (1997), Intellectual Capital: Realizing your Company's True Value by Finding its Hidden Brainpower, Harper Business, New York, NY, 240 p.

21. Europe 2020, A European strategy for smart, sustainable and inclusive growth, [Online], available at: http://ec.europa.eu/eu2020/pdf/COMPLET

22. Republic of Moldova (2018), National Development Strategy «Moldova 2020»(2019-2021), Government No. 350 vid 18 April, [Online], available at: http://lex.justice.md/viewdoc.php?action=view\&view=doc\&id=375082

23. Republic of Moldova (2017), On Accounting and Financial Reporting, Law No. 287 vid 15 December, [Online], available at: http://lex.justice.md/viewdoc.php?action=view\&view=doc\&id=363701\&lang=2

24. Ministry of Finance (2013), Presentation of Financial Statements, National Accounting Standards, Order No. 118, from August, with modification 01.01.2019, [Online], available at: http://www.old.mf.gov.md/actnorm//contabil/standartnew/

25. Nepp, A., Larionava, V., Okhrin, O. and Sesekin, A. (2018), «Optimal pension system: case study», Economics and sociology, Vol. 11(1), pp. 267-292, [Online], available at: DOI:10.14254/2071-789X.2018/11-1/18

26. Official Statistics, [Online], available at: http://www.statistica.md/newsview.php?l=ro

27. Tsurcanu, V. and Golochalova, I. (2014), The Preparation of Financial Statements in accordance with International Accounting Standards, ACAP, Chishinau, $480 \mathrm{p}$.

28. Tsurcanu, V. and Golochalova, I. (2015), «Conceptual framework for the formation of entity balance sheet», The Evolution of the Concepts of Accounting is based on the institutional approaches and benchmarking, Ruta, Zhytomyr, pp. 89-166.

29. Zamecnik, R. (2016), «The qualitative indicators in human resource accounting», Marketing i menedzhment innovacij, No. 4, pp. 325-341, [Online], available at: http://mmi.fem.sumdu.edu.ua/

** How to cite this article: Golochalova I. Pension provision recognition and assessment as a type of social capital in the context of the financial reporting socio-economic paradigm: international practice and national experience. Public Policy and Accounting. 2020, Vol. 1. https://doi.org/10.26642/ppa-2020-1-18-29 